\title{
Skjulte forbindelser? Om forholdet mellem private og offentlige kunstsamlinger
}

\author{
Hans Dam Christensen*
}

Title: Hidden liaisons? On the relation between private and public art collections.

The intention of this article is to open a debate on the too familiar dichotomy between private and public art collections. In historical and social contexts, the values as well as meanings of "private" and "public" interchange. Against this backdrop, it is tempting to question the common thinking regarding private and public collections, foremost in a Danish context. To mention just a few, more or less hidden relations: Public collections are more often than not founded on private donations and collections, and existing private collections can be open to the public as well as regulated by public legislation. In addition, private collectors can obtain a very high degree of visibility in the public sphere, they can exhibit their collections, and they can occupy important positions in the art world. Private and public collectors share common interests in visiting art fairs, knowing about upcoming galleries and artists etc., and public collectors can have their own private collections as well. In fact, we have very little research based knowledge of these liaisons.

Key words: Art museums, collections, legislation, private collectors, public sphere.

\section{Private og offentlige KUnStSAMLINGER?}

Det er fristende at opfatte "en privat kunstsamling" som modstykke til "en offentlig kunstsamling". Modstillingen af adjektiverne "privat" og "offentlig" er velkendt. Man taler eksempelvis om "privatsfære" og "offentlig sfære", og man taler om "privat sektor" og "offentlig sektor". Akronymer såsom OPS (Of-
fentlig-Privat Samarbejde) og OPP (Offentlige-Private Partnerskaber) er yndede, når erhvervsliv og politik mødes i Danmark. (Fx Dansk Erhverv 2011; Erhvervs-og Byggestyrelsen 2009). I alle tilfælde opfattes "privat" og "offentligt" som modstillede fænomener.

I det følgende er formålet trinvist at komplicere og lege med den tilsyneladende enkle modstilling mellem en privat og en offentlig 
kunstsamling. Det vil ske med udgangspunkt i et overvejende dansk eksempelmateriale, som for så vidt er velkendt, men sjældent præsenteres samlet. Men problematiseringen af de førnævnte begrebers modstilling sætter tillige materialet $\mathrm{i}$ et nyt lys. Først vil denne modstilling teoretisk blive forskubbet i lyset af en skiftende valorisering mellem det private og det offentlige i en bredere idehistorisk og social kontekst, dernæst følger en problematisering af, om man på en sådan baggrund overhovedet kan opretholde en så distinkt dikotomi mellem "offentlige" og "private" kunstsamlinger, som man møder i daglig tale. Herefter følger en række eksempler på, hvordan danske "offentlige" kunstsamlinger ikke overraskende baserer sig på "private" samlinger. Dette gør det berettiget at spørge, om der er noget, som gør den offentlige samling så meget anderledes. I artiklens sidste del diskuteres, hvordan "private" samlinger - måske mere overraskende - præges af "det offentlige", uden at der i dagligdagsforståelse er tale om offentlige kunstsamlinger. Det kan eksempelvis være, fordi private samlinger udstilles midlertidigt eller permanent, samleren er ivrig aktør på kunstscenen eller lovgivning direkte og indirekte griber ind og regulerer den private samling.

Inden artiklen når så langt, kan det tentativt hævdes, at en offentlig kunstsamling er tilgængelig for alle, og at den i en dansk sammenhæng oftest reguleres efter Museumsloven, der pålægger kunstmuseer at belyse "billedkunstens historie og aktuelle udtryk samt dens æstetiske og erkendelsesmæssige dimensioner" (Museumsloven 2006). Loven skelner mellem statslige og statsanerkendte museer, men inkluderer ikke "private museer" eller "private samlinger". For at opnå statsanerkendelse, og herigennem blandt andet få kulturministerielt tilskud til driftsmidler, skal et mu- seums område betragtes som væsentligt og ikke i forvejen være dækket af andre statslige eller statsanerkendte museer samt opfylde forskellige kvalitetskrav. Det er en teknisk detalje, men for en god ordens skyld: Statslige museer, fx et hovedmuseum som Statens Museum for Kunst, optræder i modsætning til statsanerkendte museer ikke i det kulturministerielle budget, men er direkte på Finansloven.

Det kan indtil videre, omvendt, fastholdes, at en privat kunstsamling, stor eller lille, udelukkende er baseret på en persons (eller virksomheds) kunstglæde samt købe- og indsamlingstrang uden umiddelbart hensyn til lovgivning. Metaforen "kærlighedsbørn" blev engang benyttet i et katalog over et dansk samlerpars kunstværker (Borgen 1989), i 2006 anvendte kunstmuseet Arken den gode danske titel med referencer til André Bretons L'Amour fou (1937) Mad Love - Ung kunst i danske privatsamlinger til en udstilling, og senest har kunstmuseet ARoS udstillet en privatsamling under den ligeledes gedigne titel Con Amore (2011). Betydningen af danske virksomhedslederes glæde ved kunst er velkendt for de indviede. Aage Damgaard (19171991) og tekstilvirksomheden Angli, Jarl Borgen (f. 1919) og Borgens Forlag, Peter J. Lassen (f. 1930) og reolproducenten Montana, Jørgen Nørgaard (f. 1930) og tøjbutikken Nørgaard på Strøget, Ole Faarup (f. 1934) og 3 Falkemøbler, Mads Øvlisen (f. 1940) og Novo Nordisk samt Palle Skov Christensen (f. 1953) og Jensens Bøfhus kan hurtigt nævnes, ligesom store virksomheder som Coloplast, Danalim, forsikringsselskabet Tryg og finanskoncernen Nykredit markerer sig som kunstkøbere, ofte i kraft af nuværende eller tidligere ildsjæle eller som medspillere for regionale kunstmuseer; Nykredit sponsorerer eksempelvis kunstmuseerne Louisiana Museum for 
moderne kunst, Statens Museum for Kunst og HEART (tidl. Herning Kunstmuseum) samt Kunstakademiets billedskoler. Dertil kan oplistes en række private danske fonde, lige fra $\mathrm{fx}$ Ny Carlsbergfonden over the Merla Art Foundation til Annie og Otto Johs. Detlevs Almennyttige fond såvel som Palle Dige og Kirsten Diges fond, der er stiftet af kunstsamlere, hvoraf nogle også, som vi skal se, er aktører på andre måder.

Den foreløbige pointe er, at private og offentlige kunstsamlinger oftest italesættes som modstillinger, fx bemærker dagbladet Informations anmelder i forbindelse med ovennævnte udstilling, Mad Love, at alligevel er der noget, "... der minder én om en grundlæggende forskel på den private og den offentlige kunstsamling. Nemlig den, at den offentlige samling skal reflektere fællesskabet og den nationale historie, mens den private samling kun behøver afspejle ejermandens personlige smag og æxtetiske holdning." (Damsbo 2007). Men hvor distinkte modsætninger er der egentlig tale om? Ofte er der eksempelvis tale om samlinger med overlappende kunstnere, og ofte, som vi skal se, samarbejder offentlige og private samlere.

\section{Privat og/VS OFFENTLIG}

Forholdet mellem adjektiverne "privat" og "offentlig" er ikke så ukompliceret, som det umiddelbart lyder. Der er blandt andet et værdiladet forhold mellem de to, hvor "det private" i dag har en positiv klang. Ovennævnte akronymer, OPP og OPS, antyder, at det "private" i form af virksomheder har en gavnlig indflydelse på det offentlige. Formålet kan eksempelvis være at sikre "nødvendig effektivisering og innovation" i den offentlige sektor. I den afdøde stifter af Louisiana. Museum for moderne kunst, Knud W. Jensens (19162000) bog, De glade givere (Jensen 1996), der stadig er den mest omfattende introduktion til den danske kunstsamlerhistorie, fremhæves tilsvarende de private samleres meget positive betydning for de offentlige museers samlinger. Bogens synspunkter suppleres af kataloget til Louisiana-udstillingen De glade givere - museernes bedste billeder (Jensen 1999). Af indlysende grunde fokuserer den på samlerne som givere og berører således stort set ikke alle de private stor- og småsamlere, hvis samlinger aldrig eller kun fragmentarisk er endt på offentlige kunstmuseer $\mathrm{i}$ form af enkeltdonationer og -gaver eller de enkelte museers løbende indkøb.

I en idehistorisk optik kan man omvendt sige, at i den antikke verden, med græsk oprindelse og romersk overlevering, opfattedes betydningen af ordet privatus (tilbagetrukket fra det offentlige liv) som noget negativt, fordi individets deltagelse i det offentlige var vigtig, mens den private sfære fokuserede på grundlaget for produktion og reproduktion, dvs. slavearbejde, kvinders arbejde samt fødsel og død, som alt i alt var et nødvendigt onde, "nedsunket i privatsfærens skygger", som den tyske filosof og sociolog Jürgen Habermas (f. 1929) formulerer det tilbage i 1962 (Habermas 1991: 3). Skal det formuleres meget generelt, kan man sige, at det først er senere, med liberalismens (og det borgerliges) spæde indtog, at grænserne for en privatsfære (og et civilsamfund) uden for statens rækkevidde udvides, bl.a. med henblik på dels at stække despotiske monarkers krav om at få deres magt legitimeret af Gud, dels at fremhæve individets frihedsrettigheder. Modstillingen mellem "offentlig" og "privat" har altså tidligere haft en omvendt valør, også fordi modstillingen kan bruges i mange sammenhænge, som allerede 
ovennævnte antyder. I nyere tid kan man blot pege på opbygningen af de nordiske velfærdsmodeller for at antyde et område, hvor "det private" havde en sekundær rolle. Denne kan dog omvendt imødegås af eksempelvis Christopher Lasch, når han taler om det organiserende magtapparats bureaukratiske indtrængen i privatlivet, så det personlige liv næsten er holdt op med at eksistere (Lasch 1982: 41).

Billedet er kompliceret, fordi modstillingen mellem "offentlig" og "privat" ikke hviler i sig selv, ja, faktisk kan man spørge, om den ikke snarere er teoretisk end praktisk? Og at man ved at anvende den uden selvkritik bidrager til at opretholde en illusorisk modsætning? Nogle yderligere eksempler kan illustrere problemstillingen: I mange sammenhænge er distinkte grænser mellem privatsfære og offentlig sfære eksempelvis blevet mere slørede med internet og computere. Ting, der tidligere udelukkende blev synliggjort i privatsfæren, optræder nu i en anden slags offentlig sfære, der er skabt på baggrund af enten i bredere forstand massemediernes udvikling og $\mathrm{i}$ en snæver forstand digitale medier, som let giver adgang til personers "intimsfære". Det kan eksempelvis være som en form for reality-TV (Big Brother, Paradise Hotel m.fl.) eller det kan være den enkelte bruger, som anvender blogs, web cam, hjemmeside, facebook m.m. til at præsentere intimsfæren. På et andet niveau kan det påpeges, at offentlige virksomheder, institutioner og selskaber, der tidligere var grundlæggende for udviklingen af den danske velfærdsstat (telefonselskaber, elselskaber, togdrift, postvæsen m.m.) gennem mange år er blevet privatiseret; med lidt god vilje kan man sige, at det $\mathrm{i}$ meget nyere tid kun er gået den anden vej i en dansk sammenhæng, når det statsejede selskab "Finansiel stabilitet" siden 2008 har afviklet private banker i uføre! Allerede kvindebevæ- gelsens parole om "at gøre det private offentligt", antyder dog på et tredje betydningsniveau en kritik af den for tydelige modstilling. Inden for en klassisk marxistisk tænkning ophæves grænsen mellem "privat" og "offentlig", fordi alle forhold er socialt betingede. Med 1960 ernes strukturalisme og post-strukturalisme kan man endda sige, at det menneskelige subjekt "opløses". Der findes ingen universel menneskelig identitet, fordi subjektsforståelsen består af diskurser, der løbende konstituerer subjektets selvforståelse. Det private findes slet ikke. I hvert fald ikke i sig selv.

Hos førnævnte Jürgen Habermas undersøges forholdet mellem offentlighed og privatsfære i det vestlige samfund fra de græske bysamfund og frem med hovedvægt på 1700/ 1800-tallet, hvor den moderne borgerlige offentlighed vokser frem. Han viser, at termer som "offentlighed" og "offentlig" i dag udtrykker en nedarvet sprogbrug med indre spændinger. Ikke blot hverdagssproget, mediernes og administrationens sprog, men også videnskabernes sprog er "åbenbart ude af stand til at erstatte kategorier som "offentlig" og "privat", "offentlighed" og "offentlig mening" med mere præcise udtryk". Eksempelvis er det ifølge Habermas ikke tidligere muligt at operere med en adskilt offentlig og privat sfære. Ordet "privat", som førnævnt afledt af det latinske "privatus", findes ifølge Habermas ikke på tysk før midten af det 16. århundrede. Det dækker da betydningen "uden offentligt embede". "Privat" er stadig det, som er tilbagetrukket fra det offentlige liv (Habermas 1991: 10).

\section{TILGFENGELIGE SAMLINGER}

Man kan finde mange andre eksempler, der komplicerer modstillingen mellem "privat" og "offentlig". Habermas' offentlighedsteori er 
desuden mere kompleks end anvendelsen i det forrige lader røbe. Det gør dog ikke noget, fordi flere af ovennævnte eksempler også afspejler et samfund, der er mere komplekst end det, offentlighedsteorien kan rumme. Før disse sofisterier og meget forskellige eksempler afsporer den indledende problemstilling, skal det blot konstateres, at den umiddelbart åbenlyse forskel på en privat og offentlig kunstsamling på denne baggrund måske ikke længere er så indlysende? I hvert fald bør den undersøges. En mere præcis definition på en privat kunstsamling kunne i forlængelse af ovennævnte eksempelvis være, at den ligger uden for den offentlige sfære? Eller, omvendt, at en offentlig samling er det, som ligger uden for den private sfære. Det er dog dels hierarkiske definitioner, fordi de forudsætter enten det offentliges eller privates fortrinsret, dels meget snævre definitioner, fordi det vil sige, at i det øjeblik, at eksempelvis en privat kunstsamling ikke holder sig uden for den offentliges sfære, er den ikke længere privat. Men hvad er den så? Den er jo heller ikke offentlig i dette ords hverdagsbrug. Man kan også forsøge at skelne mellem offentligt og privat ejerskab af en samling, men heller ikke denne distinktion er altid nem. Offentlige kunstsamlinger er ikke kun statslige og statsanerkendte museer, idet der findes offentlige private kunstsamlinger, som hverken er det ene eller andet. Private, men offentligt tilgængelige kunstmuseer og -samlinger i Danmark, der har været tilgængelige i en årrække, er eksempelvis Victor (1918-2002) og Kirsten Petersens store samling af J.F. Willumsen-værker, som har befundet sig på Herregården Odden siden 1989, Kirsten Kjær Museet i Frøstrup, der har været åbent siden 1981, samt Grenen Kunstmuseum, Axel Linds (1907-2011) samling af nutidig maritim nordisk kunst, inklusiv stifterens egne, som åbnede i 1977.
Omvendt kan man i en historisk optik pege på synspunkter på offentlige samlinger, der $ø$ nsker at gøre dem mere private. Det virker i en nutidig optik paradoksalt, fordi en udbredt succesparameter for et statsanerkendt museum i dag er besøgstallet, der om noget er udtryk for "offentlighed". Læser man dog en lille artikel tilbage fra 1927 af den senere direktør for Statens Museum for Kunst, Leo Swane (1887-1968), er forholdet mellem "privat" og "offentligt" ikke så entydigt:

Man kan godt rent ud indrømme, at museer er en tvivlsom form for det offentliges kunstforsorg, i virkeligheden vildskud af naturen, en abnormitet af lignende art som inden for musiklivet koncerter - beregnet ikke paa en naturlig samleven med det skønne men paa indgivelse af kunst i dosis. Museet er uundværligt, men betegner ikke den ideelle løsning; ethvert billede, ethvert stykke kunstindustri, der findes hos en privatmand og værnes dér og glæder hans øjne, er paa rette plads og bør kun gaa over til et museum, hvis den kunstneriske værdi er saa stor, at dets sikring mod brand og ødelæggelse bliver af afgørende betydning. (Swane 1927)

I bogen De glade givere bemærker Knud W. Jensen, at den første direktør for Ordrupgaard, der åbnede som statsligt museum i 1953 med blandt andet en prominent samling af moderne fransk kunst, nok sørgede for, at parken blev sat i god stand, men efter at være blevet præsenteret for Louisianas høje besøgstal bemærkede direktøren med henvisning til en nærliggende forlystelseshave, at han "var imod at lave museet om til en dyrehavsbakke" (Jensen 1996: 255).

\section{FRA PRIVAT TIL OFFENTLIG?}

Måske er forholdet mellem private og offentli- 
ge kunstsamlinger noget, som man med Habermas kan sige, vi endnu ikke har præcise ord for? I hvert fald kan man nu ikke uden videre opfatte offentlige og private kunstsamlinger som modsætninger, og det er der mange gode grunde til. Først og fremmest skyldes det, at de fleste danske kunstmuseer er grundlagt på private kunstsamlinger. I både en historisk og, til dels, nutidig optik er det nærliggende at påpege, at der inden for kunstens historie er en lang tradition for mæcener, som begrunder, at offentlige samlinger har denne baggrund, men det handler om mere end det. Det handler først og fremmest om at samle. Det er allerede synligt blandt den eksklusive gruppe på otte statslige museer, som udover Statens Museum for Kunst tæller to yderligere kunstmuseer, Den Hirschsprungske Samling og førnævnte Ordrupgaard, der hver bygger på private kunstsamlinger, hvor eksempelvis mæcenatet især for sidstnævnte samling har spillet en mindre rolle.

I 1902 overgav Pauline (1845-1912) og Heinrich Hirschsprung (1836-1908) deres samling af dansk kunst til staten, og i 1911 blev den offentlig tilgængelig. Ledelsen af Statens Museum for Kunst ønskede at indlemme Den Hirschsprungske samling i særlige rum i den eksisterende samling (Jensen, 1996: 141), men giverne ønskede en selvstændig bygning, og det blev på den modsatte side af samme park, som nationalgalleriet ligger $\mathrm{i}$, nemlig et mindre museum med rødder i den italienske renæssancevilla, der har udsigt til det store nationalgalleri; den mindre bygning svarede i givernes forståelse meget bedre til samlingens intimitet. Samlingen har foruden især sin samtids "Fynboere" og "Skagensmalere", som Hirschsprung af og til var mæcen for, også en væsentlig samling af værker af ældre danske guldalderkunstnere med vægt på skitser og studier, der stadig udstilles med respekt for det oprindelige ophængningsprincip

Ordrupgaard er et godt eksempel på, hvordan "offentlig" og "privat" kan skifte karakter og desuden kan gøre det uden hensyn til et eventuelt mæcenat. Ordrupgaard åbnede som nævnt som statsligt kunstmuseum i 1953, men privatsamlingen var $\mathrm{i}$ sin første version delvis tilgængelig for offentligheden 1-2 dage om ugen allerede tilbage i 1918, da bygningen stod færdig som herskabeligt privathjem for ægteparret Wilhelm (1868-1936) og Henny Hansen (1870-1951). På baggrund af en ambitiøs samlingsplan, allerhelst 12 malerier hver af det 19. århundredes største franske kunstnere, gjorde Wilhelm Hansen sine første køb i 1916. Allerede før århundredeskiftet havde parret en væsentlig samling af dansk kunst, der i løbet af et par år blev udvidet væsentlig med værker af Cezanne, Gauguin, Manet, Monet m.fl.

I forbindelse med den store Landmandsbanks krak i 1922 blev Wilhelm Hansen efterfølgende presset til at indfri betydelige lån i forbindelse med kunstkøbene ved at sælge værker igen. Lånene var nemlig foretaget i et konsortium, stiftet i 1918 og bestående af Hansen, kunsthandlerfirmaet Winkel \& Magnussen samt en anden af periodens store kunstsamlere, Herman Heilbuth (1861-1945), der ligeledes måtte sælge ud af sin samling, deriblandt Rembrandts Lucretia, som i dags hænger på Washington National Gallery of Art. Konsortiets formål var "Indkøb og W\&M Salg af Kunstværker med det Formaal at skaffe god og fremragende Kunst til Skandinavien”. Salgsaspektet kom ind, fordi værkerne indkøbtes "”en bloc" - eller "en gros" - med henblik på udpluk af enkeltværker og videresalg af resten." (Fonsmark 1999: 55). Indfrielseskravet i forbindelse med bankens krak medførte bort- 
salg af omkring halvdelen af samlingens værker. Selv om der kom nyerhvervelser efterfølgende, blev det aldrig helt det samme, og samlingen var kun tilgængelig efter aftale og i enkelte perioder med fast åbningsdag, før enken, Henny Hansen, testamenterede samlingen, boligen og parken til den danske stat.

Man kan spørge, hvornår Ordrupgaardsamlingen blev offentlig? Og hvornår den var privat? Den var offentlig tilgængelig lang tid, før den blev et statsligt museum, men blev undervejs privat igen inden, og ejerskabet var et stykke af vejen bundet op på et mere kompliceret ejerskab end blot den kunstglade privatsamlers eller mæcens. Og den første direktør ønskede som nævnt ikke at få museet til at ligne den nærliggende Dyrehavsbakken.

Det skal tilføjes, at Statens Museum for Kunst for så vidt også bygger på en privatsamling i moderne forstand, nemlig først dele af kongens Kunstkammer og senere den kongelige maleri- og skulptursamling, der nok havde været tilgængelig under særlige forhold, men blev åbnet for folket i løbet af 1800-tallet i samklang med udviklingen af Habermas' borgerlig offentlighed. Man kan derfor spørge om samlingen, ligesom i øvrigt ældre danske samlinger såsom A. G. Moltkes og konsul Hans West' samlinger, historisk set ikke netop har befundet sig i mellemrummet mellem en i moderne forstand privat og offentlig kunstsamling? Det var private offentlige samlinger, der dog slet ikke var tilgængelige for alle. Samlingerne var med andre ord hverken det ene eller andet, fordi distinktionen mellem privat og offentlig før 1800-tallet ikke havde samme betydning som senere.

I den store buket af statsanerkendte danske kunstmuseer, der opstod efterfølgende, findes tilstedeværelsen af private samlinger overalt. Allerede Danmarks ældste "offentlige" kunst- museum, Thorvaldsens museum, der åbnede i 1848 , baserede sig på en privatsamling, nemlig dels Bertel Thorvaldsens (1770-1844) egne værker, dels kunstnerens cirka 1000 værker af andre kunstnere. Som det fremgår af kunstnerens testamente og gavebrev fra 1838 var formålet

... at alle de ovenfor anførte Gienstande skulle udgiøre et eneste og særskilt Museum, der skal bære mit Navn, saaledes at det aldrig skal kunne blandes med hvilkesomhelst andre Samlinger, og følgeligen heller ikke formindskes, deles eller forandres under nogetsomhelst Paaskud eller af nogensomhelst Aarsag. (Thorvaldsen 1838)

Samlingen blev åbnet ved hjælp af et museumsbyggeri, der var finansieret gennem en særafgift på brænde, som passerede gennem Københavns byporte (Christensen 1912: 34). Bygningen var således $\mathrm{i}$ en nutidig optik meget direkte finansieret af offentligheden, der fik adgang til en samling, som tillige havde været tilgængelige på en mere uformel måde, dengang Thorvaldsen boede i Rom. Den findes nemlig beskrevet $\mathrm{i}$ adskillelige breve og rejsebeskrivelser.

Herefter følger en lang liste af danske, i dag statsanerkendte kunstmuseer i kronologisk rækkefølge, der bygger på private samlinger: Ny Carlsberg Glyptoteket i 1906 (Ottilia, 1854-1903, og Carl Jacobsen, 1842-1914; første del af Glyptoteket åbnede allerede 1897), Nivaagaards Malerisamling i 1908 (Johannes Hage, 1842-1923), Skagens Museum i 1908 (P. S. Krøyer, 1851-1909, Michael Ancher, 1849-1927, V. Chr. Klæbel, 1863-1941, og Degn Brøndum, 1856-1932), Faaborg Museum i 1910 (Mads Rasmussen, 1856-1916), Davids Samling i 1920 (C. L. David, 18781960) og Vejen Kunstmuseum i 1924 (Niels 
10 Hansen Jacobsen, 1861-1941). Fra denne tidlige periode kan også tilføjes væsentlige private donationer og gaver til eksisterende offentlige samlinger, ikke mindst Helge Jacobsens (1882-1946) bidrag til Glyptotekets franske samling i 1923, der blandt andet bestod af et stort antal Gauguin-værker, og Johannes Rumps (1861-1932) bidrag, især Matisse-billeder, til Statens Museum for Kunst i 1928.

I nyere tid kan man også give eksempler på, hvordan offentlige, statsanerkendte kunstmuseer, oftest med hjælp fra private fonde, har indlemmet omfattende privatsamlinger. Det nuværende Kunsten, dengang Nordjyllands Kunstmuseum, erhvervede i 1967 en stor del af Anna (1892-1962) og Kresten Krestensens (1888-1972) samling med hovedvægt på modernistisk dansk abstrakt kunst; det nuværende HEART, daværende Herning Kunstmuseum, fik i 1977 ovennævnte Aage Damgaards samling af moderne dansk og international modernistisk kunst såvel som museet overtog Damgaards nedlagte virksomhedsbygning, som blev ny museumsbygning; Kunstmuseet Trapholt modtog i 2002 Henrik og Julie Prags samling af fortrinsvis "De unge vilde"; ARoS, tidligere Aarhus Kunstmuseum, erhvervede Poul Jensens (f. 1928) donation af ligeledes fortrinsvis dansk firserkunst; og ovennævnte Kunsten fik i 2009 værker af nyere dansk kunst fra Erik Veistrups (f. 1937) samling. Hertil kan tilføjes diverse private samleres og fondes spredte donationer og gaver ud over flere danske museer. Senest har Merla Art Foundation donereret ni Damien Hirst-værker til kunstmuseet Arken ("MS" 2011).

Egentlige offentlige private samlinger, der i nyere tid har fået statsanerkendelse, er først og fremmest Louisiana, der åbnede i 1958 på baggrund i Knud W. Jensens oprindelige samling af dansk modernistisk kunst og siden ud- viklede sig hen imod en international profil, og J.F. Willumsen Museet, der åbnede året før; foruden Willumsens (1863-1958) egne værker rummer museet også en "Gammel Samling", nemlig kunstnerens samling af ældre kunst. I 1976 åbnede Carl-Henning Pedersen og Else Alfelts Museum som en slags supplement til Herning Kunstmuseum, og i 1982 åbnede det ligeledes statsanerkendte Silkeborg Kunstmuseum, der på tilsvarende vis baserede sig på en kunstner, Asger Jorn (19141973) og hans samling af egne såvel som andres værker; museet hedder i dag Museum Jorn.

\section{SYNLIGE PRIVATSAMLINGER}

Ovennævnte er en længere opremsning af offentligt tilgængelige kunstsamlinger, der har afsæt i private kunstsamlinger, og således bidrager til at problematisere forholdet mellem privat og offentlig kunstsamling. Som Ordupgaard-eksemplet viste, kan en privat kunstsamling dog godt blive offentlig, før den eventuelt bliver et tilgængelig museum. Først og fremmest er det således nærliggende at pege på privatsamlinger, der helt eller delvist udstilles. Mange enkeltværker udlånes nok i forbindelse med udstillinger, men i denne kategori er der også tale om samlinger, der udstilles som privatsamling på eksempelvis offentlige museer. I det forrige er Arkens udstilling, Mad Love (2006), nævnt. Den er bemærkelsesværdig, fordi den på den ene side tematiserede en gruppe private samleres "anderledes og sprælsk(e) billede af samtidskunsten lige nu", (Arken 2006) og på den anden side udstillede værkerne uden hensyn til deres ophav. De forskellige samleres indkøb var ophængt blandet, og flere steder måtte man nøjes med et diskret "Privateje" under værket. 
I den modsatte ende finder man eksempelvis på det allerseneste den ligeledes tidligere nævnte udstilling Con amore, et udvalg af samleren Leif Djurhuus' omkring 2000 samtidskunstværker, eller måske mere eksplicit "Hjalp! Jeg er samler" Birte Inge Christensen og John Hunous samling på Randers Kunstmuseum i 1994, som foruden billedkunst også rummede fx "design" "Africana" og "autografer"; dele af den var tillige med i udstillingen Fransk Art Nouveau keramik i Danmark - fra Kunstindustrimuseet samt John Hunovs og Birte Inge Christensens samlinger på Vejen Kunstmuseum i 1999. Dele af den keramiske samling blev senere vist på Danmarks Keramikmuseum Grimmerhus i Middelfart (2001). På Randers Kunstmuseum og Vendsyssel Kunstmuseum udstilledes i 2006 Man skal have øjnene med sig. Erik Veistrups samling, der ligesom førnævnte donation til Kunsten fortrinsvis bestod af nyere dansk samtidskunst. Som samler er Erik Veistrup dog ligesom Hunovs bredere, hvilket bl.a. også kommer til udtryk i hans overdragelse af 900 keramiske værker til Danmarks Keramikmuseum Grimmerhus i 2005. Denne del havde delvist været udstillet på Kastrupgaard i 1995 med udstillingen Huset fuldt af kunst. Erik Veistrups privatsamling.

Spørgsmålet om, hvorfor privatsamlinger udstilles, er nærliggende. I nogle tilfælde er det måske begrundet at tale om eksponering af social og kulturel kapital, selv om mange samlere historisk set har en solid økonomisk og kulturel baggrund. Der er dog mindst endnu et svar: Samleren ønsker, at privatsamlingen skal blive offentlig på permanent basis. I kataloget til udstillingen Nutidskunst fra Jytte og Jarl Borgens samling på Silkeborg Kunstmuseum og i Kunstforeningen i København i 1989, skriver Jarl Borgen således, at et væsent- ligt motiv for udstillingen er, at samlerne "har lyst til at høre om der er et dansk eller måske nordisk museum, der er interesseret $\mathrm{i}$ at overtage samlingen permanent." (Borgen 1989: 12). Tilsvarende ønske lå bag J. F. Willumsens præsentation af sin "Gamle samling" i den københavnske udstillingsbygning Charlottenborg i 1947, arrangeret af avisen Politiken og ophængt af kunstneren selv, for at vise dens betydning med henblik på en overdragelse til den danske stat (Krogh 2006: 60ff). Kunstneren havde i mange år samlet malerier, skulpturer, medaljer, plaketter, keramik, kunsthåndværk, tekstiler, tegninger og grafik. Velázquez, Tizian m.fl. var ifølge Willumsen velrepræsenterede i samlingen. Kunstnerens tilskrivninger blev dog heftigt debatteret, og selv om de også rummer fuldtræffere, bl.a. værker af El Greco og Jacopo Bassano, ja, så var de for manges vedkommende for optimistiske. Statens $\mathrm{Mu}$ seum for Kunst ville ikke modtage samlingen som gave, så først i 1957 åbnede et kommunalt museum i byen Frederikssund, som Willumsen havde familiære rødder til.

Allerede tilbage i 1919 var der kontroverser i forbindelse med en udstilling af værker fra en privat kunstsamling på Statens Museum for Kunst. Efter museets udstilling af en svensk privatsamling blev den direkte videresendt til en privat salgsudstilling, der reklamerede med den museale blåstempling. Året efter blev ovennævnte Heilbuths samling af ældre kunst anonymt udstillet på museet med et danskengelsk katalog til; det medførte også mediepolemik (Villadsen 1998: 215ff). Museets direktør, Karl Madsen (1855-1938), der ligeledes var ansvarlig for den forrige udstilling, var meget interesseret $\mathrm{i}$ at erhverve flere af billederne, især Rembrandts Lucretia, som han skrev om i Kunstmuseets Aarsskrift (Madsen 1920: 111-135). Mange år senere kan man pege på 
12 samme museums Fluxus-udstilling Hovedet gennem muren... Blocks samling (1992), der ligeledes affødte polemik på flere fronter, da den efterfølgende museumsdirektør opsagde en deponeringsaftale med den tyske ejer, Rene Block, i 1994.

Med udstillingen Johannes Rump: Portret af en samler på Statens Museum for Kunst i 1994 har man i øvrigt et eksempel på, hvor privatsamleren, der i dette tilfælde også var socialdemokratisk medlem af den københavnske borgerrepræsentation, boligspekulant og rundet af en familie, der talte onklen, landskabsmaleren Gotfred Rump, selv bliver til et historisk objekt. Baggrunden var, at det i 1928 lykkedes Rump at overdrage en stor samling af fransk modernistisk kunst, ikke mindst adskillige Matisse-malerier, til museet. Flere af værkerne havde årene forinden været udstillet på Kunstnernes Efterårsudstilling og kunstnersammenslutningen Grønningens udstillinger i København (Villadsen 1998: 247ff). Allerede i 1923 tilbød Rump første gang sin franske samling til museet, der dog måtte afslå, fordi giveren ikke ville acceptere, at den muligvis blev overdraget til Glyptoteket, som netop havde modtaget museets samling af nyere fransk kunst i bytte for en lang række værker af ældre dato. Rump lod sig dog ikke slå ud og indsamlede i de efterfølgende år - og i dialog og på fælles Paris-rejser med en museumsinspektør fra nationalgalleriet, nemlig førnævnte Leo Swane, der i 1931 blev museets direktør - værker med henblik på at få privatsamlingen til at ligne en museumssamling (Villadsen 1998: 245).

\section{SYNLIGE PRIVATSAMLERE}

Sammenblandingen af "offentlig" og "privat" kan foregå på andre måder end donationer, gaver og udstillinger. En privat kunstsamler kan nemlig på forskellige måder være aktør på kunstscenen og herigennem have mulighed for direkte og indirekte at eksponere sin samling offentligt. Med et indledende blik uden for den danske scene for privat indsamling af kunst kan ikke mindst peges på den britiske kunstsamler Charles Saatchi (f. 1943). Saatchi-samlingen har siden 1985 været udstillet i forskellige former og på forskellige steder, men har i dag etableret sig i en tilsyneladende permanent bygning i London. Selve samlingen har også skiftet indhold undervejs, og Saatchis løbende, ofte meget eksponerede salg og indkøb af værker samt omtalte tematiske udstillinger har medført, at han er blevet kritiseret for at være spekulant snarere end samler, dvs. at han aktivt har præget værkernes markedsværdi (Wu 2010). For nylig har han forsøgt at overdrage samlingen til den britiske stat, men den private samling har altså været offentlig i mange år (Bailey 2010).

Spekulation behøver dog ikke, begrundet elle ubegrundet, at være den primære grund til, at en privat kunstsamler er synlig på kunstscenen. I ovennævnte antydes eksempelvist et samarbejde mellem privatsamler Johannes Rump og museumsmanden Leo Swane. En af Swanes forgængere som direktør på Statens Museum for Kunst, Karl Madsen, der blev kritiseret for at lade en svensk såvel som dansk kunstsamler udstille på Statens Museum for Kunst, havde også tætte forbindelser med private samlere, bl.a. samme Rump såvel som andre af periodens storsamlere, fx Johannes Hage, som stod bag Nivaagaard, førnævnte Wilhelm Hansen samt Hjalmar Bruhn (18811959), der donerede værker til det nyoprettede Skagens Museum, som Madsen sad i bestyrelsen for (Jensen 1996: 155 og 191). Den tidligere nævnte Hirschsprung havde gode kontakter til kunsthistorikernen Emil Hannover 
(1864-1923), der løbende rådgav samleren og også blev museets første direktør.

Synliggørelsen kunne også tage andre former: Ordrupgaard-stifteren Wilhelm Hansen tog i 1918 initiativ til stiftelse af Foreningen Fransk Kunst med henblik på at oplyse og formidle nyere fransk kunst; blandt sine medlemmer talte foreningen Karl Madsen samt andre museumsfolk og storsamlere. Foreningens oprettelse foregik på samme tid som han oprettede sit konsortium til indkøb af samme kunst (Villadsen 1998: 200ff). Som bekendt blev det stiftet sammen med en samlerkollega og en kunsthandel, der senere også blev til et auktionshus, med henblik på storindkøb af kunst. Førnævnte Rump var også aktiv i disse år. Året før stod han bag oprettelsen af Dansk Kunsthandel. Formålet var ikke blot salg og $\mathrm{k} ø \mathrm{~b}$ af kunst, men tillige rum for udstillinger og auktioner samt produktion af kunst:

Også kunstfrembringelsen greb virksomheden ind i ved gennem kontrakter at knytte kunstnere til sig og ved at råde over fabrikationsmuligheder og atelierfaciliteter. Dansk Kunsthandel var således tænkt som en ramme, der skulle forene kunstnere, kunstfremstilling og udstillingsvirksomhed i et storstilet fælles regi. Eller, set fra et markedssynspunkt, stå for produktion samt eksport og import af kunst. (Meyer 1994)

Projektet var finansieret af Rump og fra starten ledet af maleren Viggo Madsen (18851954), søn af førnævnte direktør for Statens Museum for Kunst, Karl Madsen.

Private kunstsamlere og museumsfolk kan med andre ord indga $\mathrm{i}$ komplicerede med- og modspil. Begge parter bevæger sig på samme scene og har interesse $i$ at kvalificere deres respektive indkøb, ikke mindst $\mathrm{i}$ forbindelse med samtidskunst, samt pleje fælles interesser, fx omkring donationer, gaver og samlingskøb; i en dansk sammenhæng kan man ikke mindst pege på betydningen af kunstmuseet Louisianas erfaringer med en lang række internationale samlere med henblik på den eksisterende samling. Overlappende interessefelter er eksempelvis nationale og internationale kunstmesser og -udstillinger, aktuelle gallerier såvel som orientering i førende kunsttidsskrifter, investeringsrådgivning eller blot viden om kunstkøb i den store skala såsom Forbes' "Top Billionaire Art Collectors" (Haden-Guest 2009). I en bredere offentlighed er navne såsom Philip Niarchos, Francois Pinault og Eli Broad således ukendte, men i den internationale kunstverden er der tale om topsamlere med kunstværdier mellem anslået 1-2 milliarder dollars. Salg fra og køb til sådanne samlinger såvel som især tidligere Saatchi Collection kan på forskellig vis præge markedsværdien for bestemte kunstnere, genrer og perioder.

I en mere specifik dansk sammenhæng er eksemplerne legio. I det følgende følger en lille håndfuld eksempler, som let kan dokumenteres: Ifølge storsamleren Poul Jensen, der senere donerede dele af sin samling af de såkaldte Unge Vilde til ARoS, foretog han, museets direktør samt storsamlerne Palle Dige og Henrik Prag fællesture til kunstmesse i Køln, (Broch-Lips 2008) ligesom storsamleren Ole Faarup henviser til fælles galleriture til Berlin med kunstmuseet Arkens nuværende direktør (Andersen 2007). I 2009 bestod juryen til årets forårsudstilling på Charlottenborg, der løber helt tilbage til 1857, af fem repræsentanter hver fra ikke blot kategorier såsom "Kunstnere", "Kritikere" og "Kuratorer og museumsfolk", men også "Samlere og mæcener". Man kan også finde storsamlere i bestyrelser for danske kunstmuseer, og kunstmuseet Arkens årlige kunstpris er doneret af Annie \& Otto Johs. Detlefs" Almennyttige Fond. 
14 De større danske privatsamlere kan også selv, da knap 30 af dem med "et vist format" siden 2002 har organiseret sig i "Det danske kunstsamlerselskab" med henblik på "at have ét ansigt udadtil i forhold til kunstnere, gallerier og kunstmuseer verden over". (Andersen 2007). Selskabet arrangerer rejser, og de nyeste udstillinger samt udviklingen på kunstscenen er til debat (Faurholm 2009). Uden at kende selskabets eventuelle vedtægter gætter denne artikels forfatter på, at selskabets formål også kan være at åbne døre til eksklusive gallerier på fælles ture.

På listen "Magtens top 100” i dagbladet Information fra 2009 beskrives førnævnte Faarup som formand for selskabet og "med en enorm tilstedeværelse på den internationale kunstscene" samt som "nærmeste rådgiver" for kunstmuseet Arkens direktør (Jeppesen 2009). Et sådan udsagn skal nok tages med forbehold. Uden at det behøver at gælde alle museumsledere og storsamlere, kan begge parter som nævnt have professionel interesse i et tæt samarbejde, som ikke er odiøst, fordi parterne for så vidt også har fælles mål, og kunstmuseet Arken har siden åbningen $\mathrm{i}$ midt1990erne været i gang med at opbygge en større samling. Selve listen "Magtens top 100 ”, der har løbet i en længere periode, kan desuden ses som udtryk for, hvilke mekanismer en kunstsamler forholder sig til. På baggrund af samtaler med aktører på kunstscenen om, hvor meget en person kan gøre for en kunstner eller et værk på baggrund af "netværk, anerkendelse, økonomi og gennemslagskraft", er den udfærdiget af en kunstkritiker, der selv betegnes kunstsamler (Hornung 2006); vedkommende har tillige forfattet bogen Overblik - 63 danske samtidskunstnere (Jeppesen 2006) og er i øvrigt synlig på kunstscenen på andre måder. Kan man skelne mellem markedsføring, saglig kritik og kærlighed til kunst? I hvert fald må det være svært at holde tungen lige i munden for at bevare troværdighed. Bloggen Brask Art Blog (http:// www.braskart.com/) bestyres i øvrigt af en yngre dansk kunstsamler med tråde langt ned i den danske kunstscene, bl.a. med tætte relationer til den hippe københavnske Karriere Bar, som er udsmykket af yngre samtidskunstnere. Bloggen giver et bredt indblik i aktuelle kunstmesser, gallerier, auktioner og, ikke mindst, kunstnere, der vedrører den aktuelle kunstscene. Andre kunstsamlere har meget seriøse kunsthistoriske publikationer bag sig, ikke mindst førnævnte Hunov, der blandt andet har registreret Per Kirkebys og Richard Winthers grafiske værk i flere omgange (bl.a. Hunov 1977).

Endelig skal man med tanke for at holde tungen lige i munden blandt offentlige privatsamlere tælle de offentlige samleres, museumsfolkenes, egne samlinger. Disse lever ofte i skyggen af samlernes offentlige hverv, men kan ikke desto mindre facettere samarbejdet mellem de private og offentlige samlere, fordi sidstnævnte kan have fællesinteresser med førstnævnte, der ikke handler om den offentlige indsamling. Tilbage i 2005 donerede den internationalt kendte svenske museumsmand, Pontus Hultén (1924-2006), således 700 værker til Moderna Museet i Stockholm, som han selv havde været med til at bygge op gennem 1960erne, inden han blandt andet kom til at stå bag realiseringen af Centre Georges Pompidou, der åbnede i 1977; Hulténs eftermæle er for nylig blevet plettet af en sag om Andy Warhols Brillo Boxes, som han havde været med til at udstille - og producere? - til en Warhol-udstilling tilbage på Moderna Museet i 1968 (Levy og Scott-Clark 2010). I en dansk sammenhæng kan man henvise til førnævnte 
Karl Madsen, som foruden en stor samling af japansk kunsthåndværk (Fonsmark 2010), havde en anseelig kunstsamling, blandt andet var han ejer af C.W. Eckersbergs Skovstudie. Fra Dyrehaven (ca. 1825), der nu hænger på Ny Carlsberg Glyptotek, L.A. Rings Vinterdag i Landsbyen (1887), som i dag befinder sig på Kroppedal Museum og, formentlig, det tidligere nævnte Jacopo Bassano-maleri, Kristi Hudflettelse, der i dag hænger på J.F. Willumsens Museum. (Krogh 2005: 32ff) Blandt de større private museumssamlere skal også nævnes efterfølgeren til Madsen som direktør på Statens Museum for Kunst i perioden 19251930, nemlig den i dag mere glemte Gustav Falck (1874-1955); dele af hans samling blev af arvinger sendt på auktion i 1998 (Museumsbygningen 1998).

\section{OFFENTLIG REGULERING AF PRIVATSAMLINGER}

I artiklens indledning blev det bemærket, at en privat kunstsamling tentativt kunne siges at være "baseret på en persons (eller virksomheds) kunstglæde samt købe- og indsamlingstrang uden umiddelbart hensyn til lovgivning." I det forrige er forskellen mellem "privat" og offentlig" dog løbende blevet problematiseret med henblik på at tænke mere nuanceret over brugen, og netop med hensyn til lovgivningsaspektet opstår endnu en gråzone, hvor samspillet mellem offentlig og privat kan komme til syne. Den danske Museumslov gælder som sagt kun for statslige og statsanerkendte museer, men anden offentlig lovgivning og forvaltning kan spille ind på en privatsamlers mulighedsrum.

I De glade givere peger forfatteren Knud W. Jensen på den danske Valutacentrals betydning for stop af import af international kunst $i$ fra 1932, selv om der helt frem til Anden handel med kunst. Dette år vedtog Danmark imidlertid en ny Lov om foranstaltninger til varn for den danske valuta, som blandt andet indeholdt oprettelsen af Valutacentralen til sikring af landets valutareserver. Ifølge Knud W. Jensen "lukkede [Danmark] sig helt og aldeles ude fra kunstmarkedet, efter forbuddet $\mathrm{i}$ 1932 mod indførsel af kunst og antikviteter, som ansås for at være luksusvarer." (Jensen 1996: 286). Han tilføjer, at et lignende forbud kun kendtes i "Hitler-Tyskland, som tilmed eksporterede sine egne museers udenlandske kunst for at skaffe penge til oprustningen"; de danske restriktioner, der løb frem til 1940, ramte blandt andet samlere som Helge Jacobsen, C.L. David, Rump og Wilhelm Hansen.

Forfatteren beklager i samme bog også den danske Ligningslovs ændrede bestemmelser fra 1987 om, at museer blev udelukket "fra at modtage gaver i form af løbende ydelser med fradragsret for giveren på indtil femten procent af vedkommendes indtægt"; dette år strammedes den stadig eksisterende paragraf til kun at dække almengørende eller almennyttige foreninger, stiftelser og lignende, der kan anvende midler til miljøbeskyttelse, humanitære formål og forskning. Han mener blandt andet, at ændringen i retten til fradrag havde faet betydning for typen af indkøb for eksempelvis Kirsten og Palle Diges Fond, som nu fokuserede på indkøb af ung kunst i stedet for tidligere indkøb af langt dyrere værker af Leger, Kandinsky og Max Ernst (Jensen 1996: 514-15). Det skal tilføjes, at der siden 2006 dog har været betydeligt lempeligere danske fradragsregler om gaver til kulturinstitutioner (Kulturministeriet 2006a). Tillige er der også blevet indført nye regler, der forbedrer virksomheders mulighed for at afskrive køb af 
16 kunst, hvorfor det skulle være blevet mere attraktivt at købe kunstværker (Kulturministeriet 2006b).

Som det blandt andet fremgik af Wilhelm Hansens konsortium, kan kunst købes under mange forhold. En privat kunstsamling problematiseres sjældent i forhold til de specifikke ejerforhold, selv om købene kan være foretaget på baggrund af gældsættelse. Uden at denne artikels forfatter er specialist på hverken nuværende eller historisk ægteskabslov, arveret eller selskabslovgivning, er de forskellige italesættelser af de mange samlere og gavebreve, der ligger til grund for private kunstsamlingers overdragelse til staten, interessante i denne sammenhæng. Knud W. Jensen bemærker eksempelvis, at ingen rigtig vidste, om ovennævnte Henny Hansen var interesseret i samlingen, selv om han konkluderer, at hun til en vis grad må have været det, fordi Wilhelm Hansen løbende holdt hende ajour med indkøbene gennem telegrammer og breve. (Jensen 1996: 249) I de fleste historier om samlingen benævnes dog først og fremmest Wilhelm Hansen som den aktive part, ligesom Carl Jacobsen er den udfarende i forhold til Ottilia Jacobsen, Henrich Hirschsprung i forhold Pauline Hirschsprung, osv. Det skal tilføjes, at der findes kvinder blandt rækken af danske kunstsamlere, fx Elise Johansen (18841970), Elna Fonnesbech-Sandberg (18921994) og Jytte Dresing (f. 1929) med Merla Art Foundation, men de er få, og man kan få mistanke om, at ikke mindst arveretslige spørgsmål har afgjort, at de øvrige optræder med navn på gavebrevene.

\section{AfsLUTNING}

Hvad er så forskellen på en privat og en offentlig kunstsamling? Det forrige har forhå- bentligt vist, at forskellen i hvert fald ikke er så entydig, som den umiddelbart forekommer. Selvfølgelig er langt de fleste private kunstsamlinger private i dette ords sædvanlige betydning, fordi de kun kendes af folk i samlerens nære omgangskreds, og muligvis først får offentlighedens interesse ved arveretslige forhold. Og de fleste offentlige samlinger, ja, de er som i en dansk sammenhæng statslige og statsanerkendte samlinger, offentlige i dette ords sædvanlige betydning. Men både historisk og i dag er det muligt at pege på et indbyrdes afhængighedsforhold mellem private og offentlige samlinger, som usynliggøres under den for lette dikotomi. Der findes forskellige former for overlap og sammenhænge, hvor udstillinger og kunstmesser, indkøb og gallerier, donationer og gaver, fonde og sponsorater, bestyrelser og komiteer m.m. på forskellig vis bliver krydspunkter i kunstverdenen. Det er steder, hvor private samlere og offentlige samlere, dvs. museumsfolk, mødes og i mange tilfælde sker det, ligesom det er sket tidligere, for at pleje fællesinteresser for deres private såvel som for offentlighedens skyld.

Med Habermas kan man hævde, at modstillingen udtrykker en nedarvet sprogbrug med indre spændinger, der slører disse indbyrdes relationer. Derfor lægger ovennævnte forhåbentligt op til yderligere undersøgelser af forholdet mellem den private og den offentlige kunstsamling. Først og fremmest findes der ikke megen forskningsbaseret viden om nyere privatsamlinger i det hele taget. Ligesom "samtidskunst" først i nyere tid er blevet et egentligt forskningsområde, er det måske på tide tilsvarende at sætte et skarpere fokus på den bredere samtidskunstinstitution, eksempelvis med hensyn til privatsamlinger, marked og kunstkritik. Som det også er antydet, er 
den offentlige samlers private samling historisk såvel som i en nutidig optik næsten ubetrådt land. Der er ingen tvivl om, at private og offentlige samlere af ikke mindst nutidskunst har fællesinteresser, når de bevæger sig ud på et komplekst kunstmarked, men en mere reflekteret diskussion af, hvilke institutionelle og individuelle interesser som sættes i spil, er nødvendig. Man kan selvfølgelig antyde habilitetsproblemer, ikke mindst hvis de offentlige kunstsamlere samtidigt påberåber sig retten til at købe "den ypperste kunst" på deres institutioners vegne, fordi så enkelt er det naturligvis ikke; alene de kønnede implikationer i denne holdning bør anfægte dette. (Dam Christensen 2006). Men det behøver ikke at handle om at betvivle indkøbernes habilitet. Formålet kan lige så godt og måske hellere handle om at kortlægge og diskutere de forskellige strategier og diskurser, der tages i anvendelse for at sikre den fremtidige kunstarv. Oftest dukker viden om disse strategier og diskurser op i kunstkrikkens tilfældige artikler i dagspressens medier eller i kataloger i forbindelse med udstillinger af privatsamlinger, hvor erkendelsesinteresserne ikke altid er lige transparente. I lyset af de mange forskellige erkendelsesinteresser såvel som økonomiske interesser, som er til stede, og i lyset af den viden, der er om den nyere billedkunst, er det slående, hvor lidt forskningsbaseret viden, der egentlig er om de relationer, den indgår i.

\section{LITTERATUR}

Andersen, Magnus: "Mad Love (interviews)". Kopenhagen. Aktuel information om samtidskunst.

18.09.07. Se http://www.kopenhagen.dk/interviews/interviews/interviews_2007/interview_mad_ love/ (sidst besøgt 26.09.11)

Arken. Pressemeddelelse 2006
Bailey, Martin: "Saatchi's gift, but can the nation afford it?". The Art Newspaper 216, September 2010. Se: http://www.theartnewspaper.com/articles//21384 (Sidst besøgt 01.06.11)

Borgen, Jarl: "Kærlighedsbørn". Nutidskunst fra Jytte og Jarl Borgens samling, Kunstforeningen i København og Silkeborg Kunstmuseum. Borgens Forlag: København 1989

Broch-Lips, Henrik: "De vildes ven" (interview med Poul Jensen ved Henrik Broch-Lips). Politiken 31.05 .08

Christensen, Villads: København i Kristian den Ottendes og Frederik den Syvendes Tid 1840-1857, G.E.C. Gad: København 1912

Dam Christensen, Hans: "Køn og dømmekraft: Billedkunstens blinde punkt". Kvinder, køn og Forskning 1, 2006

Damsbo, Mads: "Kunsten at samle på kunst" (anmeldelse af Mad Love), Information 18.9.07

Dansk Erhverv. København 2011. Se http://www.danskerhverv.dk/OmDanskErhverv/Kampagner-og-temaer/OPS/Sider/fokuspaa-offentlig-privat-samarbejde-i-2009-og2010.aspx (sidst besøgt 26.09.11)

Erhvervs- og Byggestyrelsen: "Hvad er OPP?”. København 2008. Se http://www.ebst.dk/publikationer/byggeri/Offentlig- Privat_Partnerskab__Procesbeskrivelse/html/chapter02.htm (sidst besøgt 26.09.11)

Faurholm, Maria: "Interview: Ole Faarup" i Kopenhagen. Aktuel information om samtidskunst 11.06.09. Se http://www.kopenhagen.dk/index. php?id=18180 (sidst besøgt 26.09.11)

Fonsmark, Anne-Birgitte: "Giveren ... der blev mindre glad - Wilhelm Hansen på Ordrupgaard". Louisiana Revy 1, 1999

Fonsmark, Anne-Birgitte (red.): Møde med Japan. Degas, Monet, Gauguin, Toulouse-Lautrec ... Ordrupgaard: København 2010

Habermas, Jürgen: Borgerlig Offentlighet. En analyse af offentlighetens endrede struktur. Gyldendal 
Norsk Forlag: Oslo 1991 (oversættelse af Strukturwandel der Öffentlichkeit. Untersuchungen zu einer Kategorie der bürgerlichen Gesellschaft, 1962)

Hayden-Guest, Andrew: "Top Billionaire Art Collectors". Forbes.com 09.03.05. Se http://www.forbes.com/2005/03/09/cx_ahg_0309hot.html (sidst besøgt 26.09.11)

Hornung, Peter Michael: "Grimasserne lader han kunsten om" (anmeldelse af bogen Overblik. 63 danske samtidskunstnere). Politiken 02.12 .06

Hunov, John: Oeuvrekatalog over Richard Winthers grafik 1945-1960. Den danske Radeerforening: København 1977

Jensen, Knud W. (red.): Louisiana Revy 1, 1999

Jeppesen, Michael: Overblik. 63 danske samtidskunstnere. Politikens forlag: København 2007

Jeppesen, Michael: "Magtens top 100 i dansk kunst". Information 19.06 .09

Krogh, Leila:"J.F. Willumsen på sporet af El Greco". I Krogh (red.), J.F. Willumsen på sporet af El Greco. J.F. Willumsens Museum: Frederikssund 2006

Kulturministeriet: "Nyt om gaver til kulturinstitutioner". Kulturministeriet: København 2006a. http://kum.dk/Servicemenu/Publikationer/2006/Nyt-om-gaver-til-kuturinstitutioner/ (sidst besøgt 26.09.11)

Kulturministeriet: "Køb af kunst kan trækkes fra i skat". Kulturministeriet: København 2006b http://www.skat.dk/getFile.aspx?ID=6687\&new window=true (sidst besøgt 26.09.11)

Madsen, Karl: "En samling af ældre Malerkunst udstillet i Museet i Efteraaret 1920." Kunstmuseets Aarsskrift. Statens Museum for Kunst: København 1920

MS: "Damien Hirst-donation til Arken". Kunsten. $N u$ 15.09.11, se http://www.kunsten.nu/artikler/artikel.php?damien+hirst+arken+hirst+salen (sidst besøgt 26.09.11)

Museumsbygningen: Tegninger og grafik hidrørende museumsdirektor Gustav Falck, Museumsbygningen auktionshus A/S: København 1998
Lasch, Christopher: Narcissismens kultur. En analyse af et samfund i opløsning. Gyldendal: København 1982

Levy, Adrian og Scott-Clark, Cathy: "Warhol's box of tricks". The Guardian 21.08.10, se http://www.guardian.co.uk/artanddesign/2010/a ug/21/warhol-brillo-boxes-scandal-fraud (sidst besøgt 26.09.11)

Meyer, Joachim:"Johannes Rump som kunsthandler - historien om Dansk Kunsthandel (1917-19)." Lennart Gottlieb (red.): Portrat af en samler. Statens Museum for Kunst: København 1994

Museumsloven: Lovbekendtgørelse nr 1505 af $14 / 12 / 2006$

Swane, Leo: "Kunstmuseet. Et forslag til en ombygning og en omordning". Kunstbladet 1,1927

Thorvaldsen, Bertel: Testamente. København 1838. Se http://brevarkivet.thorvaldsensmuseum.dk/ emner/artikler/thorvaldsens-testamente (sidst besøgt 26.09.11)

Villadsen, Villads: Statens Museum for Kunst 18271952 Gyldendal: København 1998

Wu, Chin-tao: "YBA Saatchi? From Shark Sensation to Pastoral Painting". Ring Petersen et al. (red.), Contemporary Painting in Context. Museum Tusculanum Press: København 2010

*Hans Dam Christensen, Forskningschef, ph.d., Det informationsvidenskabelige Akademi

\section{Adresse: Det informationsvidenskabelige Akademi \\ Birketinget 6, DK-2300 København S.}

E-mail: hdc@iva.dk 